\title{
Flexion type supracondylar humerus fractures: 12 year experience of a pediatric orthopedics clinic
}

\author{
Fleksiyon tipi suprakondiler humerus kırıkları: Bir çocuk ortopedi kliniğinin 12 yıllık deneyimi
}

\author{
Ali Turgut, MD., Önder Kalenderer, MD., ${ }^{1}$ Muhammet Bozoğlan, MD., ${ }^{2}$ \\ Tayfun Bacaksız, MD., ${ }^{1}$ Haluk Ağuş, MD. ${ }^{1}$ \\ 'Department of Orthopedics and Traumatology, Tepecik Training and Research Hospital, İzmir, Turkey \\ ${ }^{2}$ Department of Orthopedics and Traumatology, Kemer State Hospital, Antalya, Turkey
}

\begin{abstract}
Objectives: This study aims to review flexion type supracondylar humerus fractures in children and treatment options.

Patients and methods: Forty-seven patients (26 males, 21 females; mean age 8.6 \pm 3.2 years; range 4 to 15 years) who admitted to and were hospitalized in a pediatric orthopedics clinic between January 2002 and January 2014 due to flexion type supracondylar humerus fracture were included in this retrospective study. Fractures were classified according to Wilkins modification of Gartland system. Closed reduction and percutaneous pinning (CRPP) were administered in all patients with type 2 and 3 fractures. An overhead traction or open reduction was applied when closed reduction could not be achieved with three manipulations. Patients were evaluated clinically and radiologically. The results were graded according to Flynn criteria.
\end{abstract}

Results: Four patients with type 1 fracture were treated conservatively. Of the remaining patients, we were able to perform CRPP successfully in 36 (83.7\%). While six patients (14\%) were treated with open reduction and internal fixation, one patient $(2.1 \%)$ was treated with overhead traction. The results were excellent or good in 44 patients $(93.7 \%)$.

Conclusion: Compared with extension type fractures, these fractures are seen in older children and are rarer. One should be prepared to perform open reduction especially for type 3 fractures. In our study, results of patients with type 3 fractures treated with CRPP were superior.

Keywords: Children; closed reduction and percutaneous pinning; flexion type; supracondylar humeral fracture.

\section{$\ddot{O Z}$}

Amaç: $\mathrm{Bu}$ çalışmada çocuklarda fleksiyon tipi suprakondiler humerus kırıkları ve tedavi seçenekleri irdelendi.

Hastalar ve yöntemler: Ocak 2002 - Ocak 2014 tarihleri arasında bir çocuk ortopedi kliniğine başvuran ve fleksiyon tipi suprakondiler humerus kırığı nedeniyle hastaneye yatırılan 47 hasta (26 erkek, $21 \mathrm{k} 1 \mathrm{z}$; ort. yaş $8.6 \pm 3.2$ yıl; dağılım 4-15 yıl) bu retrospektif çalışmaya dahil edildi. Kırıklar Gartland sisteminin Wilkins uyarlamasına göre sınıflandırıldı. Tip 2 ve 3 kırığı olan hastaların hepsinde kapalı redüksiyon ve perkütan tespit (KRPT) uygulandı. Üç manipülasyon ile kapalı redüksiyonun başarılamadığı durumda baş üzeri traksiyon veya açık redüksiyon uyguland. Hastalar klinik ve radyolojik olarak değerlendirildi. Sonuçlar Flynn kriterlerine göre derecelendirildi.

Bulgular: Tip 1 kırı $\breve{g}_{1}$ olan dört hasta konservatif olarak tedavi edildi. Geri kalan hastaların 36'sında (\%83.7) KRPT başarıyla uygulandı. Altı hasta (\%14) açık redüksiyon ve içten tespit ile tedavi edilirken bir hasta $(\% 2.1)$ baş üzeri traksiyon ile tedavi edildi. Kırk dört hastada (\%93.7) sonuçlar mükemmel veya iyi idi.

Sonuç: Ekstansiyon tipi kırıklar ile karşılaştırıldıklarında, bu kırıklar daha büyük yaşlı çocuklarda görülmektedir ve daha nadirdir. Özellikle tip 3 kırıklar için açık redüksiyon uygulamaya hazır olunmalıdır. Çalışmamızda KRPT ile tedavi edilen tip 3 kırıklı hastaların sonuçları daha iyi idi.

Anahtar sözcükler: Çocuklar; kapalı redüksiyon ve perkütan telleme; fleksiyon tipi; suprakondiler humerus kırığı.

- Received: July 15, 2015 Accepted: October 13, 2015

- Correspondence: Ali Turgut, MD. Tepecik Eğitim ve Araştırma Hastanesi Ortopedi ve Travmatoloji Kliniği, 35120 Konak, İzmir, Turkey. Tel: +90 537-0274425 Fax: +90232-4330756 e-mail: draliturgutort@yahoo.com.tr 
Supracondylar humeral fractures (SHF) constitute 50 to $60 \%$ of all elbow fractures in children. ${ }^{[1]}$ Extension type SHFs are well described and represented in the literature. Flexion type SHFs are uncommon types of supracondylar fractures and were reported to account for only 2 to $10 \%$ of distal humerus fractures in children. ${ }^{[2-6]}$ Flexion type SHFs are thought to require open reduction more often than extension types and probability of iatrogenic or preoperative nerve injury is also higher. ${ }^{[5]}$ There are various described techniques about the treatment of these injuries in the literature such as manipulation and casting in flexion or extension, overhead traction, closed reduction and percutaneous pinning (CRPP), and open reduction and internal fixation (ORIF). ${ }^{[7]}$ These described treatment options are based on a limited number of small sized case series because there are not much data about these fractures in the literature.

Our unit serves as a pediatric trauma center in a city populated with approximately four million people. Treatment of SHF is a common practice of our clinic due to the larger number of referrals from peripheral hospitals. Therefore, we decided to evaluate our treatment options for flexion type SHF. Therefore, in this study, we aimed to review flexion type SHFs in children and treatment options.

\section{PATIENTS AND METHODS}

Forty-seven patients (26 males, 21 females; mean age $8.6 \pm 3.2$ years; range 4 to 15 years) who had been hospitalized with a diagnosis of SHF in Pediatric Orthopedics Clinic of Tepecik Training and Research Hospital between January 2002 and January 2014 were evaluated retrospectively. This study was approved by the local ethical committee (12.05.2015-number 2). Inclusion criteria were patients with flexion type injury diagnosed on a conventional elbow anteroposterior and lateral radiograph with a minimum follow-up of 12 months. There were totally 1,189 patients with SHF and 64 of them had flexion type injury (5.4\%). The patients with flexion type injury were treated by five different surgeons. Forty-seven patients who had 12 months and longer follow-up time were included in this study.

Patients' files were gathered from the hospital's archive according to their diagnosis. Patients' preoperative radiographs, sex, postoperative radiographs, accompanying skeletal injuries, and operation notes were evaluated from these files. Follow-up radiographs and examination notes were gathered from out-patient information files. Fractures were classified using Wilkins modification of Gartland system ${ }^{[6]}$ In our routine practice, patients are questioned for symptoms and daily activities at each out-patient clinic control. The range of motion of flexion and extension, pronation, and supination are also measured using a goniometer and compared with the uninjured side as a standard protocol. The carrying angle is measured with a goniometer clinically. The other arm is used as a control. The measurement of the range of motion and the carrying angle were performed by five different surgeons. After evaluating these results which were gathered from outpatient information files, they were graded according to the scale presented by Flynn et al. ${ }^{[8]}$ (Table I). Anterior humeral line, Baumann angle and lateral capitellar angle measurement were performed by the first author on the last follow-up radiographs. Nerve injuries and infection were recorded as complication.

As part of the protocol for pediatric SHF treatment in our clinic, all fractures which are thought to be unstable undergo surgical fixation in the operating room within the first eight hours from admission. Surgery is performed in the evening or midnight if admission takes place outside working hours. Closed reduction and percutaneous pinning is our first choice of treatment for these fractures. If closed reduction cannot be obtained after three attempts, open reduction or overhead traction is performed to decrease the possibility of the occurrence of iatrogenic nerve or vascular injury by further closed manipulations.

In closed reduction technique for type 3 flexion type fractures, longitudinal traction is applied from the forearm of the injured extremity while the elbow is held in about $10^{\circ}$ of flexion and then the elbow is brought to $90^{\circ}$ of flexion while applying downward pressure from the forearm (Figure 1). The reduction is confirmed by anteroposterior fluoroscopic view and then the lateral view is seen by rotating the $\mathrm{C}$-arm laterally rather than rotating the elbow. If the reduction is acceptable, the fracture is pinned firstly laterally and then medially. Medial pin is inserted by palpation of the medial epicondyle after lessening the flexion of the elbow to avoid iatrogenic ulnar nerve injury.

TABLE I

Criteria for Flynn grading

\begin{tabular}{lcc}
\hline Rating & $\begin{array}{c}\text { Function: } \\
\text { loss of motion }\left(^{\circ}\right)\end{array}$ & $\begin{array}{c}\text { Appearance: } \\
\text { change in carrying angel }\left(^{\circ}\right)\end{array}$ \\
\hline Excellent & $0-5$ & $0-5$ \\
Good & $6-10$ & $6-10$ \\
Fair & $11-15$ & $11-15$ \\
Poor & $>15$ & $>15$ \\
\hline
\end{tabular}


Technique of CRPP after changing flexion type fracture into extension type was used by the senior author in three patients with severely displaced type 3 flexion type fractures. Longitudinal traction was applied from the forearm and the elbow was hyper flexed while maintaining distal fragment medially to avoid possible iatrogenic ulnar nerve injury which can occur by end of the proximal fragment. The radial and median nerves are safe because of their anterior position. The distal fragment was then manipulated posteriorly while proximal fragment was forced anteriorly. Once the fracture is changed into extension type, one should know that both anterior and posterior periosteum are torn and the fracture is now type 4 extension type fracture. Therefore, the fracture has to be fixed accordingly. After three weeks from the surgery, long arm casts are removed and active elbow motions are started.

\section{Statistical analysis}

Only descriptive statistics are present in this study and PASW version 17.0 for windows (SPSS Inc., Chicago, IL, USA) was used for statistical analysis.

\section{RESULTS}

Mean follow-up time was 21.5 \pm 9.3 (range, 12-44) months. According to the modification of the Gartland system by Wilkins, there were four fractures in type 1

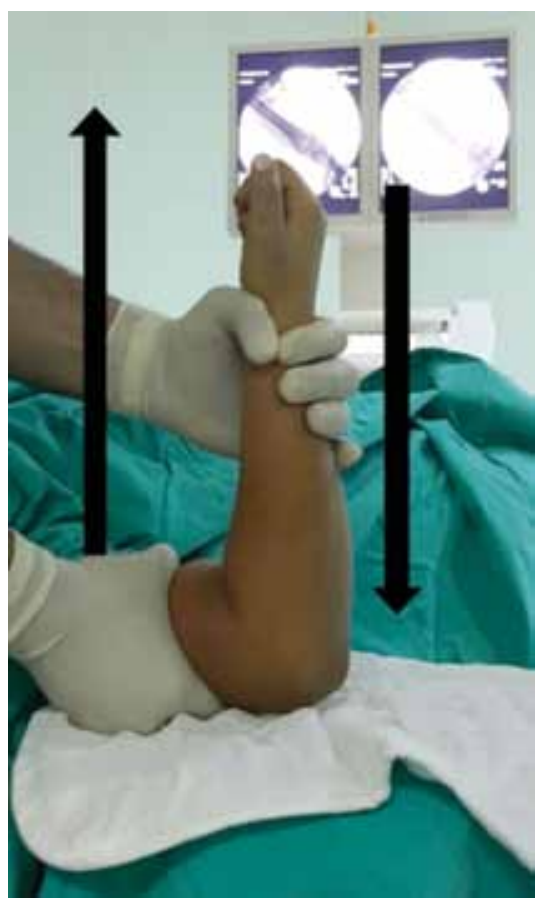

Figure 1. Reduction maneuver for correction of flexion deformity.
$(8.6 \%), 21$ fractures in type $2(44.6 \%)$, and 22 fractures in type $3(46.8 \%)$. None of the patients had vascular injury preoperatively.

Four patients with type 1 fracture were treated with posterior long arm splint in $90^{\circ}$ elbow flexion. Remaining 43 fractures which were type 2 or 3 were treated operatively. We were able to perform CRPP in 32 patients $(74.4 \%)$; open reduction and internal fixation via lateral exposure were needed in six patients $(14 \%)$ because of unsuccessful attempts of closed reduction (Figure 2a-d). Due to surgeon's preference not to perform open reduction, overhead (olecranon) traction was applied in the operating room in five patients $(11.6 \%)$ in which adequate reduction could not be achieved after three manipulations (Figure $3 a$ and $b$ ). After five to seven days from the injury, four of these patients were reoperated and CRPP could be applied successfully (Figure 3c). The other patient with overhead traction could not be operated because of his pneumonia and was treated by overhead traction for two weeks and then posterior splint for additional two weeks. Crossed pin configuration was performed for all fixations. Obtained treatment modalities for each type of fracture are summarized in Table II.

Baumann angle could not be measured in eight patients who were between 11 and 15 years-old because of the closure of capitellar physis. Mean Baumann angle was measured as $75.5^{\circ} \pm 4.7$ (range, 65-84) in 39 patients and it was observed that there were seven patients with more than $5^{\circ}$ differences compared with the other elbow. Mean lateral capitellar angle was $39.1^{\circ} \pm 10.8$ (range, 5-72) and mean carrying angle was $11.4^{\circ} \pm 3.3$ (range, 2-17). The anterior humeral line was found to intersect central $1 / 3$ capitellum in 29 patients, anterior $1 / 3$ capitellum in 10 patients and posterior $1 / 3$ capitellum in eight patients. These results are shown in Table III according to the treatment groups.

Ulnar nerve palsy was observed in three of the patients with type 3 fractures preoperatively (6.4\%). Iatrogenic ulnar nerve palsy was observed in two patients (4.2\%) who had type 2 and type 3 injuries, respectively. Probably, Kirschner wire which passed from medial side caused this complication. The medial Kirschner wires were not removed until the fracture was healed. Whole ulnar nerve palsy symptoms recovered fully in these five patients averagely in 2.8 months (range, 6 weeks to 6 months).

There were two accompanying skeletal injuries (one Salter Harris type 2 distal femur physeal injury and one distal radius fracture) in patients who both had type 3 fracture. 

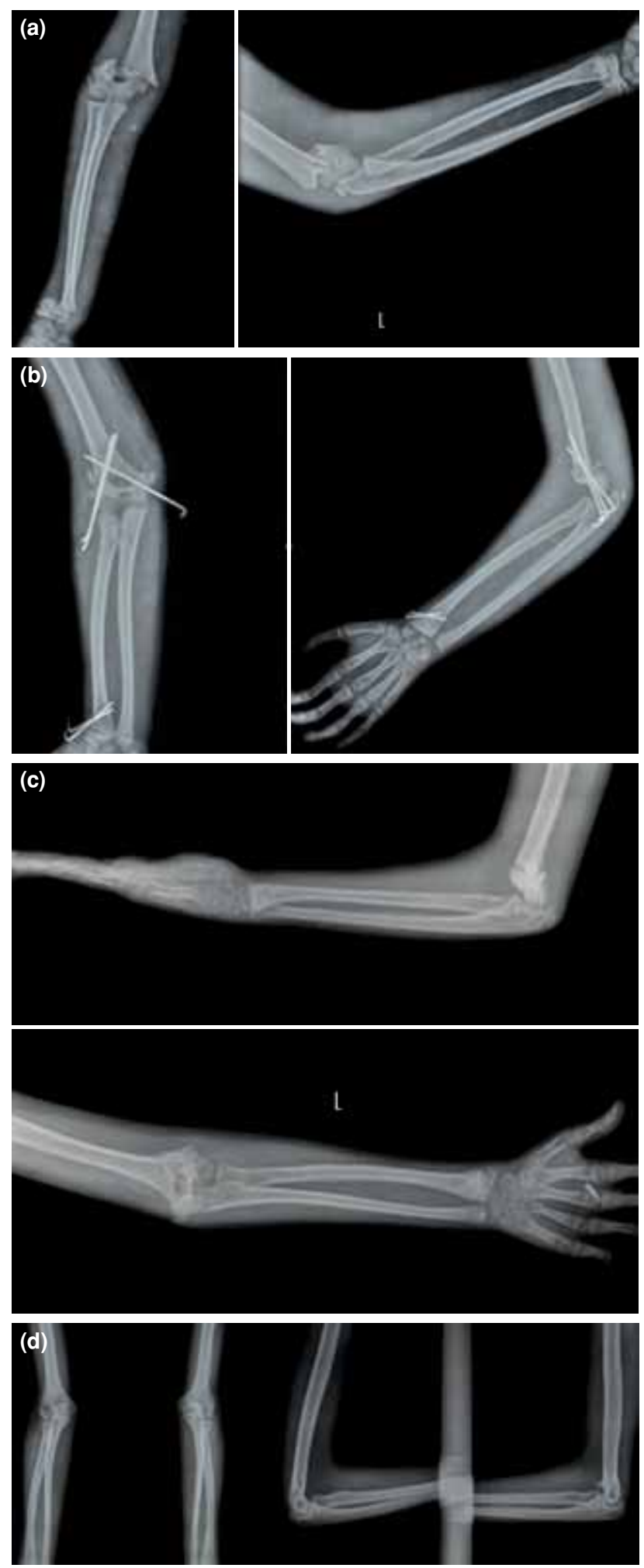

Figure 2. (a) Preoperatively taken radiographs of an 11-yearold female patient with type 3 and distal radius fractures. (b) Postoperative radiographs after open reduction and internal fixation. (c) Radiographs after healing of fractures. (d) Comparison radiographs with uninjured elbow after 44 months follow-up showing remodeling of hyperextension deformity.
The fractures had been changed into extension type in three patients with type 3 fracture and then cross pinned by hyper flexion of the elbow. Additional nerve injury was not observed in these patients whose reductions were obtained by changing them into extension type although one of them already had ulnar nerve palsy preoperatively. The results were excellent in 36 patients $(76.6 \%)$, good in eight patients $(17.1 \%)$, fair in two patients $(4.2 \%)$ and poor in one patient $(2.1 \%)$ according to Flynn criteria (Table IV). ${ }^{[8]}$ Poor result was obtained in the patient who was treated with overhead
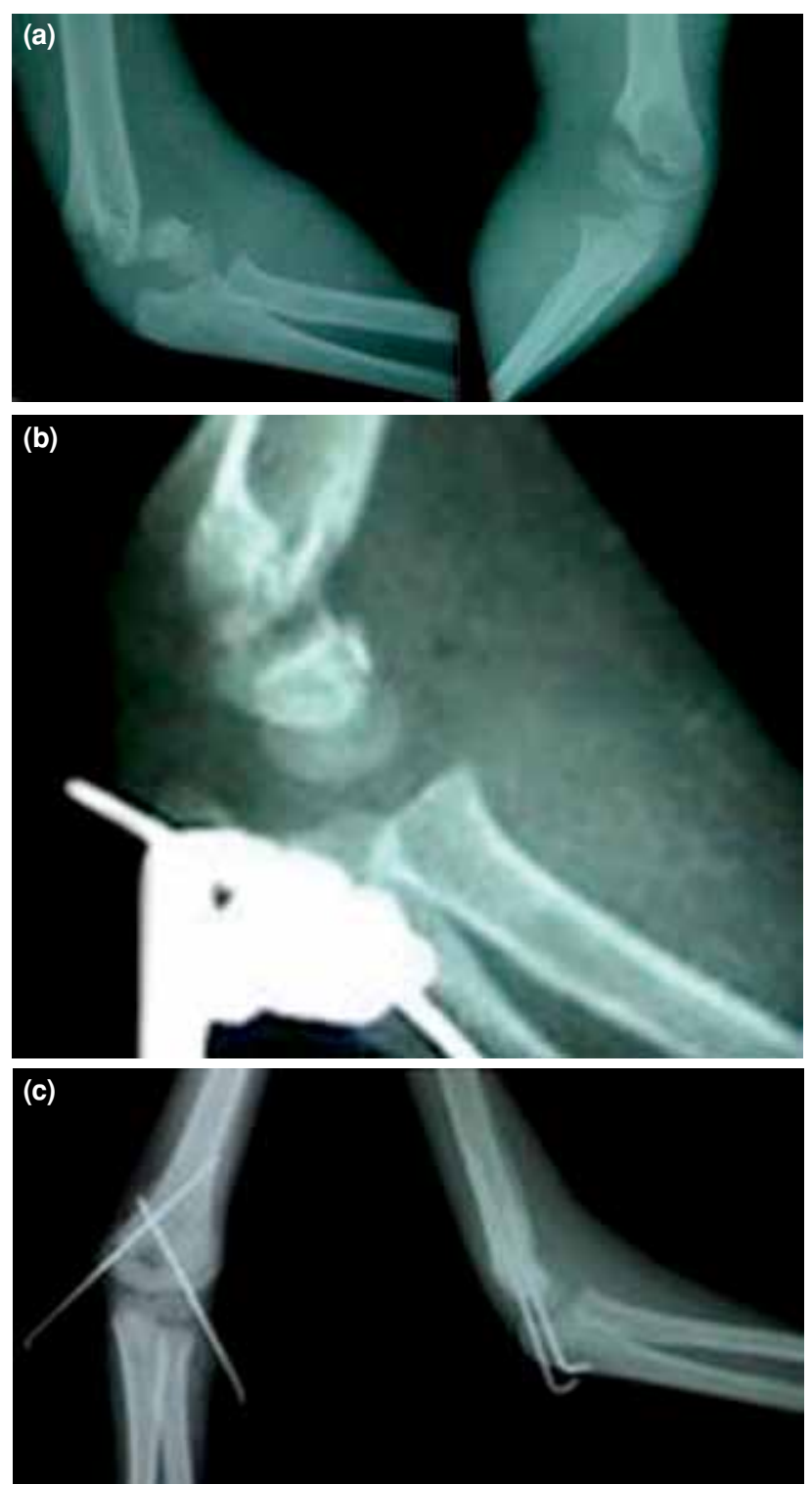

Figure 3. (a) Anteroposterior and lateral radiograms of a six-year-old female patient with flexion type 3 supracondylar humeral fracture. (b) Lateral radiograms of skeletal traction of olecranon at fifth day after fracture. (c) Anteroposterior and lateral radiograms after closed reduction and percutaneous pinning. 
TABLE II

Treatment modalities according to each type of fractures

\begin{tabular}{lccccc}
\hline & $\begin{array}{c}\text { Conservative } \\
(n=4)\end{array}$ & $\begin{array}{c}\text { CRPP } \\
(n=32)\end{array}$ & $\begin{array}{c}\text { CRPP after OHT } \\
(n=4)\end{array}$ & $\begin{array}{c}\text { ORIF } \\
(n=6)\end{array}$ & $\begin{array}{c}\text { OHT } \\
(n=1)\end{array}$ \\
\hline Type 1 $(n=4)$ & 4 & - & - & - & - \\
Type 2 $(n=21)$ & - & 21 & - & - & - \\
Type 3 $(n=22)$ & - & 11 & 4 & 6 & 1 \\
\hline
\end{tabular}

CRPP: Percutaneous pinning; OHT: Over-head traction; ORIF: Open reduction and internal fixation.

traction and had $30^{\circ}$ extension limitation at his $14^{\text {th }}$ months of follow-up.

\section{DISCUSSION}

Flexion type SHF is a rare subgroup of elbow fractures in children. In the literature, there is not enough data about features and treatment alternatives of these fractures. Our study's major findings were that CRPP could not be performed in half of the patients with type 3 fracture as the first treatment but in type 2 fractures CRPP was the choice of treatment for all patients.

De Boeck ${ }^{[3]}$ published a review of 29 flexion type SHFs which were followed-up for at least one year after the injury. In his series, a predominance of males was seen. The mean age was 8.3 years and it was higher than the children with extension type fractures (6.2 years) treated during the same period. In the series of Mahan et al., ${ }^{[5]} 58$ flexion type SHFs were compared with a control group of 192 extension type fractures. In their study, there were considerably more females than males in flexion group. The mean age was 7.5 years in flexion group and 5.8 years in extension group. However, there were nearly equal males and females in our series (26 males and 21 females). The mean age of our study group was
8.6 years. Our findings were similar with the study of De Boeck.

The management of supracondylar fractures of the humerus in children should focus on gaining full range of motion at the end of the treatment. There are different treatment options such as simple cast immobilization, overhead traction, closed reduction and percutaneous pinning, open reduction and internal fixation, and overhead traction and delayed percutaneous pinning. These treatment modalities can be chosen according to patient's age, type of fracture, and soft tissue condition as well as surgeon's experience and preference. Type 1 fractures are usually treated with simple cast immobilization. Extension splinting or CRPP can be preferred in type 2 fractures. ${ }^{[2,3,9]}$ Closed reduction and percutaneous pinning, open reduction and internal fixation or skeletal traction and delayed percutaneous pinning are common treatment options for type 3 fractures..$^{[1-12]}$ Type 3 fractures are more unstable fractures and treatments of these fractures are more difficult due to increased soft tissue injuries which will help and hold the reduction.

According to modification of Gartland system, De Boeck ${ }^{[3]}$ has classified seven fractures as type 1 ,

TABLE III

Results of anterior humeral line, Baumann angle, lateral capitellar angle and carrying angle measurements for each treatment group

\begin{tabular}{|c|c|c|c|c|c|c|c|}
\hline & \multicolumn{3}{|c|}{$\begin{array}{l}\text { Anterior humeral line } \\
\text { (patient number) }\end{array}$} & \multicolumn{2}{|c|}{$\begin{array}{l}\text { Baumann angle difference } \\
\text { (patient number) }\end{array}$} & \multirow{2}{*}{$\begin{array}{c}\text { Lateral } \\
\text { capitellar } \\
\text { angle }\left(^{\circ}\right)\end{array}$} & \multirow{2}{*}{$\begin{array}{l}\text { Carrying } \\
\text { angle }\left(^{\circ}\right) \\
\text { Meanly }\end{array}$} \\
\hline & $\begin{array}{l}\text { Anterior 1/3 } \\
\text { capitellum }\end{array}$ & $\begin{array}{l}\text { Central 1/3 } \\
\text { capitellum }\end{array}$ & $\begin{array}{l}\text { Posterior 1/3 } \\
\text { capitellum }\end{array}$ & More than $5^{\circ}$ & Below than $5^{\circ}$ & & \\
\hline Conservative $(n=4)$ & - & 4 & - & - & 4 & 38.8 & 11.3 \\
\hline CRPF $(n=32)$ & 6 & 20 & 6 & 4 & 28 & 39.5 & 11.8 \\
\hline $\mathrm{OHT}+\mathrm{CRPF}(\mathrm{n}=4)$ & 2 & 2 & - & 1 & 3 & 41 & 10.5 \\
\hline ORIF $(n=6)$ & 2 & 3 & 1 & 1 & 5 & 29.8 & 10.3 \\
\hline $\mathrm{OHT}(\mathrm{n}=1)$ & - & - & 1 & 1 & - & 72 & 2 \\
\hline
\end{tabular}

CRPF: Closed reduction and percutaneous pinning; OHT: Over-head traction; ORIF: Open reduction and internal fixation. 
TABLE IV

Evaluation of patients according to Flynn et al. ${ }^{[8]}$ criteria

\begin{tabular}{|c|c|c|c|}
\hline & Type 1 & Type 2 & Type 3 \\
\hline & $\mathrm{n}$ & $\mathrm{n}$ & $\mathrm{n}$ \\
\hline Excellent & 4 & 17 & 15 \\
\hline Good & 0 & 3 & 5 \\
\hline Fair & 0 & 1 & 1 \\
\hline Poor & 0 & 0 & 1 \\
\hline
\end{tabular}

nine fractures as type 2, and 13 fractures as type 3 in their study. They applied simple immobilization with elbow flexion between $90^{\circ}$ and $40^{\circ}$ in type 1 fractures. All of the other fractures were treated with closed reduction and percutaneous pinning. In another study, there were 12 fractures in type 2, and 44 fractures in type 3 . The types of two fractures could not be determined. All fractures underwent surgical reduction and pinning. 40 fractures were reduced closely while 18 were treated with open reduction. ${ }^{[5]}$ In this study, all patients who required open reduction had type 3 fractures except one who had type 2. Need for open reduction was $39 \%$ in type 3 fractures. We attempted CRPP to all patients within first eight hours of the injury. We were unsuccessful in $11(25.6 \%)$ of them which were all type 3 injuries. Insertion of Kirschner wires to hold the reduction is more difficult in these injuries because the reduction can be obtained in extension. ${ }^{[7]}$ Changing the flexion type 3 injury to unstable extension type injury. ${ }^{[13]}$ can make the insertion of the wires easier in flexion position as we performed in three patients.

Ulnar nerve is at risk with flexion type SHFs. ${ }^{[3,14,15]}$ In Mahan et al.'s series, ulnar nerve symptoms were present in 11 patients (18\%) and four of them were found to be compressed in the fracture site. ${ }^{[5]}$ Fowles et al. ${ }^{[4]}$ reported three ulnar nerve injuries in 17 patients $(17.6 \%)$. De Boeck ${ }^{[3]}$ reported two ulnar nerve injuries in his series (6.9\%). In the present study, $13.6 \%(n=3)$ of type 3 fractures had ulnar nerve symptoms preoperatively. Although we had performed lateral exposure for open reduction, medial exposure can be more reliable and safer to explore the ulnar nerve for the fractures that have ulnar nerve symptoms preoperatively in which open reduction is needed as stated by Steinman et al. ${ }^{[16]}$

In De Boeck's ${ }^{[3]}$ series, $86 \%$ of patients had excellent and good results and $14 \%$ had fair results according to Flynn criteria. Our results were similar with De Boeck's series. Only one patient was treated with overhead traction because of his pneumonia and extension of his elbow was found to be restricted $\left(30^{\circ}\right)$ at the final follow-up.

Mahan et al..$^{[5]}$ had performed ORIF in 39\% of their patients and they were successful in CRPP in the remaining. De Boeck $^{[3]}$ had performed CRPP successfully for all of the displaced flexion type injuries. In another study, which was consisted of 14 patients, open reduction was necessary for four patients $(28.5 \%) \cdot{ }^{[13]} \mathrm{In}$ the present study, open reduction was required for $27.3 \%(n=6)$ of type 3 fractures. Although open reduction is accepted as a good option for these fractures' treatment, our study demonstrates favorable results in patients who are treated by CRPP (Table V). So, we think that CRPP after a period of overhead traction in patients in which closed reduction cannot be obtained is still a good option.

This study has some limitations. First of all, this is a retrospective study. Long-term results of the patients are lacking. The patients' characteristics with extension type supracondylar fractures were not evaluated as a control group who had admitted in the same period. Limited patient number can be considered as a limitation but there are few reports with mostly limited number of patients about this entity in the literature.

In conclusion, these fractures are usually seen in older children and are rarer injuries compared with extension types. Changing the flexion type fractures

TABLE V

Results of type 3 fractures according to Flynn criteria

\begin{tabular}{lccc}
\hline & $\begin{array}{c}\text { Open reduction and } \\
\text { internal fixation }\end{array}$ & $\begin{array}{c}\text { Closed reduction and } \\
\text { percutaneous pinning } \\
(\mathrm{n}=6)\end{array}$ & $\begin{array}{c}\text { Closed reduction and } \\
\text { percutaneous pinning after } \\
\text { overhead traction } \\
(\mathrm{n}=4)\end{array}$ \\
\hline Excellent & 1 & 11 & 3 \\
Good & 4 & - & 1 \\
Fair & 1 & - & - \\
Poor & - & - & - \\
\hline
\end{tabular}


into extension type can offer easier pin placement but this technique needs to be studied in larger number of patients. In type 3 flexion fractures, it can be difficult to reduce the fracture by closed means so one should be prepared to perform open reduction or overhead traction. Results of CRPP procedures seem to be favorable than ORIF for patients with type 3 fracture.

\section{Declaration of conflicting interests}

The authors declared no conflicts of interest with respect to the authorship and/or publication of this article.

\section{Funding}

The authors received no financial support for the research and/or authorship of this article.

\section{REFERENCES}

1. Kumar R, Kiran EK, Malhotra R, Bhan S. Surgical management of the severely displaced supracondylar fracture of the humerus in children. Injury 2002;33:517-22.

2. Williamson DM, Cole WG. Flexion supracondylar fractures of the humerus in children: treatment by manipulation and extension cast. Injury 1991;22:451-5.

3. De Boeck H. Flexion-type supracondylar elbow fractures in children. J Pediatr Orthop 2001;21:460-3.

4. Fowles JV, Kassab MT. Displaced supracondylar fractures of the elbow in children. A report on the fixation of extension and flexion fractures by two lateral percutaneous pins. J Bone Joint Surg [Br] 1974;56:490-500.

5. Mahan ST, May CD, Kocher MS. Operative management of displaced flexion supracondylar humerus fractures in children. J Pediatr Orthop 2007;27:551-6.

6. Wilkins KE. Fractures and dislocations of the elbow region. In: Rockwood CA Jr, Wilkins KE, King RE, editors. Fractures in children. Philadelphia: Lippincott; 1991. p. 526-617.

7. Garg B, Pankaj A, Malhotra R, Bhan S. Treatment of flexiontype supracondylar humeral fracture in children. J Orthop Surg (Hong Kong) 2007;15:174-6.

8. Flynn JC, Matthews JG, Benoit RL. Blind pinning of displaced supracondylar fractures of the humerus in children. Sixteen years' experience with long-term followup. J Bone Joint Surg [Am] 1974;56:263-72.

9. El-Sharkawi AH, Fattah HA. Treatment of displaced supracondylar fractures of the humerus in children in full extension and supination. J Bone Joint Surg [Br] 1965;47:273-9.

10. Ağuş H, Kalenderer O, Kayali C, Eryanilmaz G. Skeletal traction and delayed percutaneous fixation of complicated supracondylar humerus fractures due to delayed or unsuccessful reductions and extensive swelling in children. J Pediatr Orthop B 2002;11:150-4.

11. Omid R, Choi PD, Skaggs DL. Supracondylar humeral fractures in children. J Bone Joint Surg [Am] 2008;90:1121-32.

12. Kotwal PP, Mani GV, Dave PK. Open reduction and internal fixation of displaced supracondylar fractures of the humerus. Int Surg 1989;74:119-22.

13. Leitch KK, Kay RM, Femino JD, Tolo VT, Storer SK, Skaggs DL. Treatment of multidirectionally unstable supracondylar humeral fractures in children. A modified Gartland typeIV fracture. J Bone Joint Surg [Am] 2006;88:980-5.

14. Wilkins KE. The operative management of supracondylar fractures. Orthop Clin North Am 1990;21:269-89.

15. Babal JC, Mehlman CT, Klein G. Nerve injuries associated with pediatric supracondylar humeral fractures: a metaanalysis. J Pediatr Orthop 2010;30:253-63.

16. Steinman S, Bastrom TP, Newton PO, Mubarak SJ. Beware of ulnar nerve entrapment in flexion-type supracondylar humerus fractures. J Child Orthop 2007;1:177-80. 